\title{
Produksi Akuakultur dan Dampak Nutrifikasi Perairan Danau Tondano
}

\author{
Aquaculture Production and the Impact of Nitrification Waters of Lake Tondano
}

\author{
Meilona P. Rawung, Indra R.N. Salindeho, Sipriana Tumembouw
}

\begin{abstract}
This study was conducted to determine the level of aquaculture production Tondano and determine the impact of the production level of the waters of Lake Tondano nutrifikasi . The data collected in this study, consisting of primary data and secondary data. Production data obtained from the questionnaire and interviews to farmers fish there, as well as data obtained from the Department of Fisheries and Village Head Office. Water sampling to determine levels of phosphate in the waters of the lake . Water sampling conducted on six (6) locations: Village Ranomerut, Eris Village , Village Paslaten, Leleko Village, Village and Village Paleloan Toulour. Sampling was conducted at six (6) points to pay attention to the position of the inlet and outlet of the waters of Lake Tondano. Tondano aquaculture production in 2014 was estimated at 1222.12 tons / year. Number KJT operated as many as 978 units. There was a decrease in aquaculture production annually over a period of $2001-2014$. Followed by the declining number of KJT on Lake Tondano. Phosphates were donated to the waters of fish farming activities from the rest of the feed pellets. The content of orthophosphate in the waters of Lake Tondano of $0.06 \mathrm{mg} / \mathrm{I}$ means the waters of the lake are in a safe condition Tondano not pass the specified limits ( PP RI No. 82 of 2001 ) . The decline in aquaculture production decline followed Tondano phosphorus content in Lake Tondano. Another factor that is expected to also affect the amount of water hyacinth around the lake so that the phosphorus content is also on the wane .

keywords : Lake Tondano, Production, Nutrification
\end{abstract}

\section{PENDAHULUAN}

Fungsi dari Danau Tondano yaitu merupakan sumberdaya yang penting dan strategis bagi perekonomian di Sulawesi Utara (Rondo dan Soeroto, 1990; Wantasen dan Kereh, 2001). Hal ini dapat dilihat dari manfaat gandanya berupa sumber bahan pangan bergizi (ikan), sumber air untuk industri, air minum (PAM Manado), sumber energi (PLTA Tanggari), media transportasi, pariwisata dan juga digunakan sebagai areal budidaya (Rondo dan Soeroto, 1990; Wantasen dan Kereh, 2001).

Aktivitas budidaya di Danau Tondano dengan menggunakan sistem Kurungan Jaring Apung (KJA) ataupun Kurungan Jaring Tancap (KJT) telah berkembang dengan pesat (Mantau, 2014). Produksi akuakultur yang dihasilkan di Danau Tondano pada tahun 2001 sebanyak 15.423 ton/tahun (DKP-FPIK, 2001), sedangkan produksi akuakultur Danau Tondano pada tahun 2003 sebanyak 16.576 ton/tahun dan nilai tersebut merupakan produksi akuakultur tertinggi yang pernah dicapai Danau Tondano. Namun sejak saat itu produksi akukultur terus menurun, penurunan yang signifikan terjadi dari tahun 2003 sampai 2005 dimana produksi akuakultur Danau Tondano sebanyak 3869,27 ton/tahun (Wehantow, 2005), bahkan pada tahun 2009 dimana trisakti (2012) melaporkan produksi akuakultur Danau Tondano sebanyak 1.234 ton/tahun, itu berarti produksi akuakultur Danau Tondano jatuh pada titik terendah.

Kadar fosfat di Danau Tondano cenderung semakin meningkat dari tahun ke tahun (Arifin, 2003). Data yang didapat pada beberapa tahun terakhir ini kadar fosfat di perairan 
Danau Tondano juga menurun. Kadar fosfat di Danau Tondano pada tahun 2003 yaitu sebesar $1,3 \mathrm{mg} / \mathrm{l}$, nilai ini merupakan nilai tertinggi jika dibandingkan dengan data kadar fosfat di Danau Tondano pada tahun-tahun berikut. Pada tahun 2011 kadar fosfat sebesar 0,37 mg/l, untuk tahun 2012 kadar fosfat sebesar $0,12 \mathrm{mg} / \mathrm{l}$, bahkan pada tahun 2013 kadar fosfat di Danau Tondano sebesar 0,04 $\mathrm{mg} / \mathrm{l}$. Berdasarkan data tersebut dapat dilihat bahwa kadar fosfat di Danau Tondano juga mengalami penurunan dengan bertambahnya waktu.

Berdasarkan uraian di atas, maka perlu dilakukan penelitian untuk mendapatkan data produksi akuakultur dan kondisi lingkungan perairan Danau Tondano khususnya kadar fosfat yang terkandung agar dapat diketahui sejauh mana pengaruh produksi tersebut terhadap kandungan fosfat yang ada di Danau Tondano.

\section{METODE}

Penelitian dilakukan selama 3 bulan dimulai dari Bulan Februari 2014 hingga Mei 2014. Data yang dikumpulkan dalam penelitian ini, terdiri dari data primer dan data sekunder. Data primer dikumpulkan dari hasil kuesioner, wawancara dan pengukuran langsung di lapangan. Data sekunder dikumpulkan dari kepustakaan dan laporan penelitia lainnya.

Data produksi diperoleh dari hasil kuesioner dan wawancara ke petani-petani ikan yang ada di sekeliling danau pada sentra-sentra produksi budidaya, dan juga data yang didapat dari Dinas Perikanan dan Kantor Lurah.

Pengambilan sampel air untuk mendapatkan kadar fosfat di perairan dilakukan pada 6 (enam) lokasi yaitu Desa Ranomerut, Desa Eris, Desa Paslaten, Desa Leleko, Kelurahan Paleloan dan Kelurahan Toulour. Pengambilan sampel air dilakukan di 6 (enam) titik dengan memperhatikan posisi inlet dan outlet perairan Danau Tondano. Pengambilan sampel air menggunakan botol lamouth. Pada tiap lokasi, pengambilan sampel air dilakukan pada dua kedalaman yaitu pada $0 \mathrm{~m}$ (permukaan) dan $5 \mathrm{~m}$. Botol sampel yang telah berisi air dimasukkan ke dalam kotak pendingin (cool box) yang berisi es.

\section{Analisis Data}

Data produksi akuakultur dan kandungan $P$ perairan danau dianalisis deskriptif, disajikan dalam bentuk tabel dan beberapa bentuk diagram. Kandungan $P$ Danau Tondano dibandingkan dengan standar baku mutu kualitas air yang ditetapkan oleh pemerintah RI PP No. 82 tahun 2001. Selanjutnya dilakukan analisis komparasi dengan data kepustakaan, dokumen-dokumen serta laporan penelitian sebelumnya. Data fluktuasi produksi dan fluktuasi kadar $P$ sejak tahun 2001-2014 dianalisis regresi dan korelasi untuk melihat tren penurunan produksi dan penurunan kadar $P$ Danau Tondano.

\section{HASIL DAN PEMBAHASAN}

\section{Produksi Akuakultur Danau Tondano tahun 2014}

Hasil penelitian ini menunjukkan bahwa produksi akuakultur di Danau Tondano diperkirakan sebesar 1211,754 ton/tahun. Jumlah KJT yang dioperasikan mencapai 1030 unit (Tabel 1). Jika dibandingkan dengan data produksi lain yang diperoleh pada tahun-tahun sebelumnya, diperoleh data terakhir pada tahun 2009 produksi akuakultur sebesar 1234 ton/tahun dengan 5347 unit KJT yang beroperasi, produksi akuakultur Danau Tondano pada tahun 2014 memiliki nilai yang terendah.

Berdasarkan data yang ditampilkan pada Tabel 1 dan Gambar 1 pada tahun 2014 aktifitas akuakultur dilakukan di 10 desa sekeliling Danau Tondano yaitu Desa Ranomerut, Desa Eris, Desa Telap, Desa Watumea, 
Desa Toulour, Desa Paleloan, Desa Paslaten, Desa Leleko, Desa

Toulimembet dan Desa Urongo. Hal berbeda ditunjukkan pada tahun 2005 berdasarkan penelitian Wehantow (2005) produksi akuakultur dilakukan di 17 desa sekeliling Danau Tondano. Hal ini berarti aktifitas akuakultur Danau Tondano sudah jauh berkurang dari tahun-tahun sebelumnya, dapat dilihat berdasarkan data yang diperoleh banyak desa-desa yang sudah tidak berproduksi lagi dengan kata lain aktifitas akuakultur yang ada di desa tersebut telah mati. Beberapa desa yang sudah tidak melakukan aktifitas akuakultur seperti Desa Tandengan, Desa Kaweng, Desa Kaima, DesaTalikuran, Desa sinuian dan Desa Tounelet.

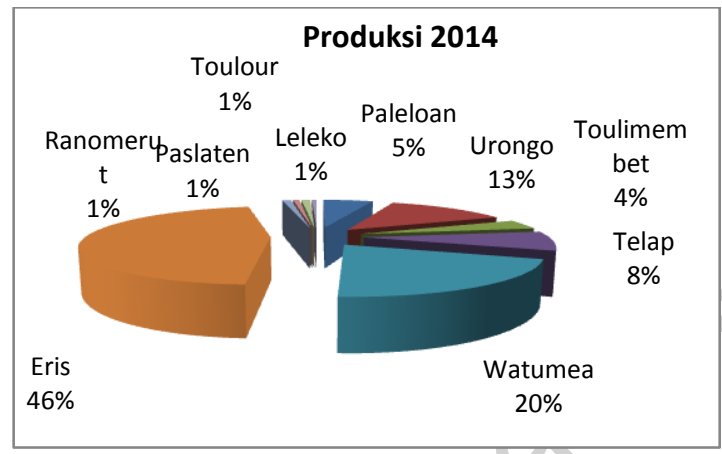

Gambar 2 menunjukkan bahwa pada tahun 2014 sentra-sentra produksi akuakultur ada di desa-desa pesisir Timur danau yang merupakan bagian dari Kecamatan Eris yaitu Desa Eris dan Desa Watumea. Terdapat perbedaan pada tahun 2005 produksi akuakultur berada di 3 sentra utama yaitu Desa Telap, Desa Eris dan Desa Tandengan (Wehantow, 2005). Hal ini berarti terjadi penurunan produksi pada Desa Telap dan terjadi peningkatan produksi di Desa Watumea, sedangkan produksi akuakultur di Desa Tandengan pada tahun 2014 sudah tidak ada lagi. Desa Eris dan Desa Watumea menyumbang $66 \%$ dari total produksi akuakultur di Danau Tondano.

\section{Faktor-faktor yang Mempengaruhi Produksi Faktor lingkungan}

Lingkungan merupakan salah satu aspek penting terhadap berhasilnya suatu usaha akuakultur. Danau Tondano yang merupakan perairan umum atau terbuka banyak dimanfaatkan oleh berbagai pihak untuk kepentingannya masing-masing, sehingga sulit untuk dilakukan kontrol terhadap lingkungan perairan danau. Penurunan produksi akukultur terjadi secara konsisten akibat dari berbagai faktor penyebab.

Berdasarkan informasi yang didapat dari para pembudidaya ikan, setiap tahunnya ada fenomena alam yang terjadi yang menyebabkan ikan dalam keadaan lemas bahkan kematian masal secara tiba-tiba. Gejala alam ini oleh para pembudidaya ikan dikenal dengan istilah "ranolewo" ( yang artinya: air jahat ). Ada 2 macam "ranolewo" yang dikenal oleh pembudidaya yang dapat mengancam akuakultur yaitu air belerang dan air dingin

Selain masalah fenomena alam seperti yang sudah dijelaskan di atas tadi terdapat juga masalah lain yang mengancam lingkungan perairan Danau Tondano yaitu nutrifikasi. Berdasarkan penelitian yang telah dilakukan di danau besar dan kecil, ternyata fosfat merupakan elemen kunci dalam proses nutirfikasi.

Salah satu sasaran yang dianggap menjadi penyebab nutrifikasi di Danau Tondano adalah melalui aktivitas akuakultur. Fosfat yang disumbangkan ke

dalam perairan dari aktivitas akuakultur berasal dari sisa pakan pelet yang terbuang dan sisa kotoran ikan akuakultur (Nastiti $d k k, 2001$ ).

Dengan mengetahui jumlah produksi akuakultur dan volume air danau kita dapat menghitung jumlah sumbangan $P$ ke dalam perairan. Produksi akuakultur pada tahun 2014 sebesar 1.211 ton/tahun, apabila 
diasumsikan 1 ton produksi menyumbang $27 \mathrm{~kg} \mathrm{P}$ (Beveridge, 1987) ke dalam danau maka dengan jumlah produksi yang ada sekarang dapat diketahui jumlah total sumbangan $P$ dari produksi yang ada pada saat ini ke dalam danau sebesar $32.697 \mathrm{~kg}(\mathrm{P})$. Nilai total sumbangan $P$ ke dalam danau dibagi dengan volume air danau maka akan didapatkan jumlah sumbangan $P$ ke dalam danau yaitu sebesar $0,06 \mathrm{mg} / \mathrm{l}$.

Persamaan regresi linear untuk waktu dan produksi mengindikasikan bahwa selang waktu antara 2001-2014, setiap tahun terjadi penurunan produksi akuakultur Danau Tondano sebesar 1132,15 ton/tahun. Nilai ' $r$ ' menginformasikan bahwa ada hubungan yang korelasi yang sangat kuat antara waktu dan produksi akuakultur Danau Tondano. Selanjutnya persamaan regresi linear untuk waktu dan jumlah KJT mengindikasikan bahwa selang waktu 2001-2014, setiap tahun terjadi penurunan jumlah KJT yang dioperasikan di Danau Tondano sebesar 619,705 unit. Nilai ' $r$ ' menginformasikan bahwa ada hubungan korelasi yang sangat erat antara waktu dan jumlah KJT yang beroperasi di Danau Tondano. Setelah itu persamaan regresi linear untuk waktu dan kandungan fosfat mengindikasikan bahwa selang waktu 2001-2014, setiap tahun terjadi penurunan kandungan fosfat di Danau Tondano sebesar 0,1209 mg/l. Nilai ' $r$ ' menginformasikan bahwa ada hubungan korelasi yang sangat erat antara waktu dan kandungan fosfat di Danau Tondano.

\section{Faktor Ekonomi}

Salah satu penyebab lain menurunnya produksi ikan di perairan Danau Tondano yaitu naiknya harga pakan pelet yaitu berkisar antara Rp. 400.000 - Rp. 470.000 per karung yang berakibat biaya produksi budidaya ikan semakin meningkat. Para petani tidak memiliki modal yang cukup banyak untuk menjangkau harga pakan yang saat ini mengalami kenaikan.

Harga pakan ikan yang secara reguler meningkat, sementara harga jual ikan yang cenderung tetap merupakan penyebab penting turunnya produksi ikan di perairan Danau Tondano.Harga beberapa produk pakan yang dipakai para pembudidaya saat ini berkisar antara Rp. $400.000-$ Rp. 470.000 per karung dengan berat $50 \mathrm{~kg}$. Hal ini berarti $1 \mathrm{~kg}$ pakan harus di bayar pembudidaya dengan harga Rp. 8.000 - Rp. 9.400. Harga jual ikan produk budidaya di lokasi Danau berfluktuasi antara Rp. 20.000 - Rp. 22.000 / kg. Jika FCR untuk pemeliharaan ikan nila dan mujair di KJT sebesar 2,0 (Beveridge, 1987) maka untuk biaya pakan, petani harus mengeluarkan dana sebesar $\mathrm{Rp}$. 18.800 jika menggunakan pakan seharga Rp. 9.400 / kg. Jika ditambahkan harga pembelian benih, upah tenaga kerja dan lain-lain biaya operasioanal, maka pembudidaya tidak mampu menutup total biaya operasional.

Dengan contoh di atas maka, meningkatnya harga pakan tanpa diikuti dengan meningkatnya harga ikan, akan sangat menyulitkan para pembudidaya ikan. Dampak dari keadaan ini adalah nilai profit semakin kecil, bahkan pada kondisi tertentu pembudidaya ikan tidak mendapat keuntungan sama sekali melainkan akan mendapatkan kerugian. Hal tersebut juga yang akhirnya menyebabkan banyaknya para pembudidaya ikan yang gulung tikar atau menutup usahanya.

\section{Faktor Teknis Budidaya}

Penerapan teknik budidaya yang baik, tepat dan benar sangat menentukkan keberhasilan suatu usaha budidaya yang pada akhirnya menentukan nilai produksi ikan. Beberapa teknis budidaya yang dipraktekkan oleh para pembudidaya di Danau Tondano seperti : 
Kegiatan budidaya ikan di perairan Danau Tondano dilakukan di sepanjang bagian pesisir danau dengan kedalaman perairan berkisar antara 5-10 m. Metode budidaya yang digunakan yaitu Keramba Jaring Tancap 'Fixed Net Cage', yang menggunakan tiang-tiang bambu sebagai patok tempat ikat kurungan jaring, sehingga operasional budidaya tidak dapat dilakukan pada areal perairan yang lebih dalam.

Ukuran benih yang ditebar bervariasi antara $5 \mathrm{~cm}$ sampai $15 \mathrm{~cm}$, namun yang paling dominan adalah ukuran 5-8 cm. Sebagian besar pembudidaya yang ada di Danau Tondano tidak lagi membeli benih di luar atau di tempat-tempat produsen benih lainnya, karena sebagian besar dari mereka telah menggunakan benih ikan yang mereka produksi sendiri.Adapun sebagian kecil pembudidaya di Danau Tondano yang mendapatkan atau membeli benih dari pembudidaya sekitar yang ada di Danau Tondano. Harga benih bervariasi antara Rp. 200 - Rp. 500.

Selama pemeliharaan, ikan diberi pakan dalam bentuk pellet yang merupakan produk komersial dari beberapa produsen pakan ternak.Pemberian pakan tidak memperhatiakn nilai FCR 'Food Conversion Ratio' melainkan pemberian pakan masih menggunakan teknik ad libitum yaitu pemberian pakan sepuasnya sampai ikan tidak lagi memakan pelet yang diberikan. Merek pakan yang digunakan bervariasi seperti Hiprovite, Komfit, Bintang Provite dan yang paling dominan adalah merek Central Protein, dengan harga pakan antara Rp. 400.000 - Rp. 470.000 untuk 1 karung.

Berdasarkan pengamatan di lapangan selama penelitian, metode pemberian pakan yang tidak memperhatikan aturan pemberian pakan yang efektif dan efisien, dimana dosis pemberian pakan antara 3-5\% per total berat ikan pada tiap kantong, melainkan pemberian pakan secara ad libitum yaitu pemberian pakan sebanyak-banyaknya dengan melihat ikan tidak merespon lagi lagi terhadap pakan yang diberikan. Alasan lain pemberian jumlah pakan yang banyak yaitu agar ikan cepat "besar" ada juga sebaliknya pemberian pakan dibawah kebutuhan ikan adalah untuk penghematan, karena harga pakan yang sangat mahal.

Teknis budidaya yang pada umumnya tidak memperhatikan padat penebaran yang diatur dengan baik. Sebangian kantong ditebar dengan kepadatan yang tinggi, sedangkan yang lain ditebar dengan kepadatan yang rendah. Pemeliharaan dengan kepadatan tinggi sangat beresiko, dimana kebutuhan Oksigen yang meningkat, sedangkan ketersediaan Oksigen di air sangat rendah.

\section{Kesimpulan}

Berdasarkan data yang diperoleh lewat penelitian ini dapat ditarik sejumlah kesimpulan :

- Produksi akuakultur Danau Tondano pada tahun 2014 diperkirakan sebanyak 1.211,574 ton/tahun. Jumlah KJT yang dioperasikan sebanyak 1030 unit. Terjadi penurunan produksi akuakultur setiap tahunnya pada selang waktu 2001 - 2014. Diikuti dengan menurunnya jumlah KJT di Danau Tondano.

- Selang waktu antara 20012014, setiap tahun terjadi penurunan produksi akuakultur danau tondano sebesar 1132,15 ton/tahun, dan terjadi penurunan jumlah KJT yang dioperasikan sebanyak 619,705 unit serta terjadi penurunan kandungan fosfat sebanyak $0,12088 \mathrm{mg} / \mathrm{l}$ setiap tahunnya di Danau Tondano.

- Ada hubungan korelasi yang kuat antara waktu dengan jumlah produksi akuakultur, antara waktu dengan jumlah 
KJT dan antara waktu dengan kandungan fosfat di Danau Tondano.

- Ada 3 faktor penting yang mempengaruhi produksi akuakultur Danau Tondano yaitu : lingkungan, ekonomis dan teknis budidaya.

- Rataan kandungan P di perairan Danau Tondano sebesar 0,04 $\mathrm{mg} / \mathrm{l}$ artinya perairan Danau Tondano berada pada kondisi aman tidak melewati batas yang ditentukan (PP RI Nomor 82 Tahun 2001).Berdasarkan jumlah produksi Danau Tondano kandungan $P$ yang diasumsikan dihasilkan melalui aktivitas budidaya sebesar 0,06 mg/l pada tahun 2014.

- Menurunnya produksi akuakultur Danau Tondano diikuti penuruan kandungan fosfat yang ada di Danau Tondano. Pertumbuhan enceng gondok yang tidak terkendali menjadi salah satu penyebab penurunan fosfat di perairan Danau Tondano.

\section{Daftar Pustaka}

Anonimous. 2013.

Demonstrasi

Budidaya

Ikan Air Tawar Secara Intensif di

KJA Danau Tondano. Pusat

Penyuluhan Kelautan dan

Perikanan.

Arifin H. 2003. Daya Dukung Perairan

Danau Tondano dengan

Parameter Fosfor (P) untuk

Menunjang Kegiatan Budidaya

Ikan. Skripsi. Fakultas

Perikanan dan IImu Kelautan,

Unsrat Manado. 48 halaman.

Beveridge M.C.M. 1987. Cage

Aquaculture. Fishing News

Books Ltd, England. 352 p.

Hastuti Y.P, Nirmala K, Setioaji T. 2012.

Kemampuan Penyerapan

Nitrogen dan Fosfor dalam

Lingkungan Budidaya oleh
Kijing Taiwan gravestone Anadonta woodiana Lea. Jurnal Akuakultur Indonesia, Departemen Budidaya Perairan Fakultas Perikanan dan IImu Kelautan, IPB Bogor, 11 (1) : 86-95.

Kamsuri A.I, Pangemanan N.P.L, Tumbol

R.A. 2013. Kelayakan Lokasi

Budidaya Ikan Di Danau Tondano Ditinjau Dari Parameter Fisika Kimia Air. Jurnal Budidaya Perairan. 1 (3) : $31-42$.

Maniagasi R, Tumembouw S.S, Mudeng

Y. 2013. Analisis Kualitas Fisika Kimia

Air di Areal Budidaya Ikan

Danau Tondano Provinsi

Sulawesi Utara. Jurnal

Budidaya Perairan, 1 (2) : 29 37.

Nastiti A.S, Nuroniah S,

Purnamaningtyas

S.E, dan Kartamihardja E.S.

2001.

Daya Dukung Perairan Waduk Jatiluhur untuk Budidaya Ikan dalam Keramba Jaring Apung. Jurnal Penelitian Perikanan Indonesia, 7 (2) : 14-21.

Rondo M dan Soeroto B. 1990. Kondisi Ekologis Perairan Danau Tondano. Berita Fakultas Perikanan, UNSRAT, 1 (2) : 5863.

Trisakti B. 2012. Penguatan Kapasitas

Untuk Pemanfaatan Data Inderaja

Ekstraksi Informasi Kualitas Danau Bagi Kesesuaian Budidaya Perikanan Darat Dan Kelestarian Lingkungan Di Danau Tempe Dan Tondano. Laporan Penelitian. Insentif Peningkatan Kemampuan Peneliti Dan Rekayasa Kementrian Riset Dan Teknologi. 42 hal.

Tumembouw S.S. 2012. Kualitas Air Pada 
Perairan

Lokasi Budidaya Ikan Di

Desa Eris, Danau Tondano,

Kabupaten Minahasa. Jurnal

Perikanan Dan Kelautan Tropis.

8 (1) : 33-36.

Wantasen S dan Kereh M.R. 2001.

Penurunan Kualitas Air DAS

Tondano di Sulawesi Utara.
Ekoton, Jurnal Lingkungan Hidup dan Sumber Daya Alam, 1 (1) : 29-32

Wehantow A. 2005. Fluktuasi Produksi Ikan Budidaya Perairan Danau Tondano. Skripsi. Fakultas Perikanan, Unsrit. 36 halaman.

Tabel 1. Produksi akuakultur danau tondano serta jumlah KJT yang dioperasikan pada tiap desa produsen selang waktu 2001-2014

\begin{tabular}{|c|c|c|c|c|c|c|c|c|}
\hline \multirow[b]{2}{*}{ Desa } & \multicolumn{2}{|c|}{2001} & \multicolumn{2}{|c|}{2003} & \multicolumn{2}{|c|}{2005} & \multicolumn{2}{|c|}{2014} \\
\hline & $\begin{array}{c}\text { Jumlah } \\
\text { KJT }\end{array}$ & $\begin{array}{l}\text { Produksi } \\
\text { (ton) }\end{array}$ & $\begin{array}{c}\text { Jumlah } \\
\text { KJT }\end{array}$ & $\begin{array}{l}\text { Produksi } \\
\text { (ton) }\end{array}$ & $\begin{array}{c}\text { Jumlah } \\
\text { KJT }\end{array}$ & $\begin{array}{l}\text { Produksi } \\
\text { (ton) }\end{array}$ & $\begin{array}{c}\text { Jumlah } \\
\text { KJT }\end{array}$ & $\begin{array}{l}\text { Produksi } \\
\text { (ton) }\end{array}$ \\
\hline Watumea & 375 & 474 & 600 & 600 & 388 & 466 & 170 & 248,344 \\
\hline Tandengan & 1520 & 3420 & 720 & 1728 & 884 & 1127 & 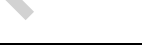 & \\
\hline Toulimembet & 250 & 281 & 1000 & 1200 & 1210 & 1270 & 40 & 48,375 \\
\hline Eris & 2500 & 4218 & 2000 & 3600 & 1005 & 829 & 440 & 556,874 \\
\hline Ranomerut & - & - & - & - & 54 & 69 & 20 & 11,81 \\
\hline Toliangoki & - & - & - & - & 20 & 26 & - & - \\
\hline Telap & 3000 & 3796 & 3000 & 3600 & 751 & 1014 & 105 & 95,8125 \\
\hline Paleloan & 450 & 405 & 375 & 338 & 222 & 233 & 67 & 65,8125 \\
\hline Urongo & 48 & 92 & 48 & 87 & 36 & 38 & 130 & 158,402 \\
\hline Toulour & 375 & 270 & 200 & 260 & & & 20 & 8,437 \\
\hline Tounelet & 300 & 338 & 300 & 405 & 265 & 278 & - & - \\
\hline Paslaten & 50 & 45 & 80 & 48 & 48 & 50 & 20 & 11,812 \\
\hline Tasuka & - & - & - & - & 64 & 62 & - & - \\
\hline Kaweng & 60 & 86 & 60 & 108 & 202 & 227 & - & - \\
\hline Kaima & 100 & 60 & 150 & 90 & 130 & 137 & - & - \\
\hline Talikuran & 150 & 90 & 120 & 72 & 30 & 32 & - & - \\
\hline Sinuian & 20 & 11 & 30 & 15 & 35 & 37 & - & - \\
\hline Leleko & 32 & 18 & 24 & 22 & 27 & 28 & 18 & 6,075 \\
\hline Taler & 30 & 22,5 & 30 & 24 & - & - & - & - \\
\hline Kiniar & 60 & 45 & 60 & 48 & - & - & - & - \\
\hline Roong & 75 & 105 & 75 & 140 & - & - & - & - \\
\hline Tuutu & 36 & 27 & 36 & 36 & - & - & - & - \\
\hline Rerewokan & 36 & 27 & 36 & 36 & - & - & - & - \\
\hline total & 8099 & 15423,8 & 8944 & $16.576,80$ & 5374 & 3869,27 & 1030 & 1211,75 \\
\hline
\end{tabular}

Ket : data 2001 (DKP-FPIK, 2001), data 2003 (Arifin, 2003), data 2005 (Wehantow, 2005) 
Tabel 2. Data Hasil Parameter Kandungan Nitrat Dan Fosfat Pada Beberapa Titik Lokasi Pengambilan Sampel Di Danau Tondano

\begin{tabular}{|c|c|c|c|c|}
\hline \multirow{2}{*}{$\begin{array}{c}\text { Lokasi } \\
\text { Pengambilan } \\
\text { Sampel }\end{array}$} & \multirow{2}{*}{ Kedalaman } & \multicolumn{2}{|c|}{$\begin{array}{c}\text { Parameter yang } \\
\text { diamati }\end{array}$} & \multirow[b]{2}{*}{ Laboratorium } \\
\hline & & $\begin{array}{l}\text { Nitrat } \\
(\mathrm{mg} / \mathrm{l})\end{array}$ & $\begin{array}{l}\text { Fosfat } \\
(\mathrm{mg} / \mathrm{l})\end{array}$ & \\
\hline \multirow{2}{*}{ Ranomerut } & $0 \mathrm{~m}$ & 0,13 & 0,02 & \multirow{12}{*}{ Baristan } \\
\hline & $5 \mathrm{~m}$ & 0,16 & 0,03 & \\
\hline \multirow{2}{*}{ Paleloan } & $0 \mathrm{~m}$ & 0,10 & 0,01 & \\
\hline & $5 \mathrm{~m}$ & 0,16 & 0,04 & \\
\hline \multirow{2}{*}{ Leleko } & $0 \mathrm{~m}$ & 0,16 & 0,02 & \\
\hline & $5 \mathrm{~m}$ & 0,29 & 0,08 & \\
\hline \multirow{2}{*}{ Paslaten } & $0 \mathrm{~m}$ & 0,52 & 0,07 & \\
\hline & $5 \mathrm{~m}$ & 0,20 & 0,20 & \\
\hline \multirow{2}{*}{ Toulour } & $0 \mathrm{~m}$ & 0,11 & 0,01 & \\
\hline & $5 \mathrm{~m}$ & 0,14 & 0,03 & \\
\hline \multirow{2}{*}{ Eris } & $0 \mathrm{~m}$ & 0,13 & 0,02 & \\
\hline & $5 \mathrm{~m}$ & 0,13 & 0,03 & \\
\hline \multirow[t]{2}{*}{ Watumea } & $0 \mathrm{~m}$ & - & 0,543 & \multirow{4}{*}{$\begin{array}{l}\text { Water } \\
\text { Laboratory } \\
\text { Nusantara }\end{array}$} \\
\hline & $5 \pi$ & & 0,033 & \\
\hline \multirow{2}{*}{ Eris } & $0 \mathrm{~m}$ & & $\begin{array}{l}0,02 \\
0,03\end{array}$ & \\
\hline & $5 \mathrm{~m}$ & & & \\
\hline
\end{tabular}

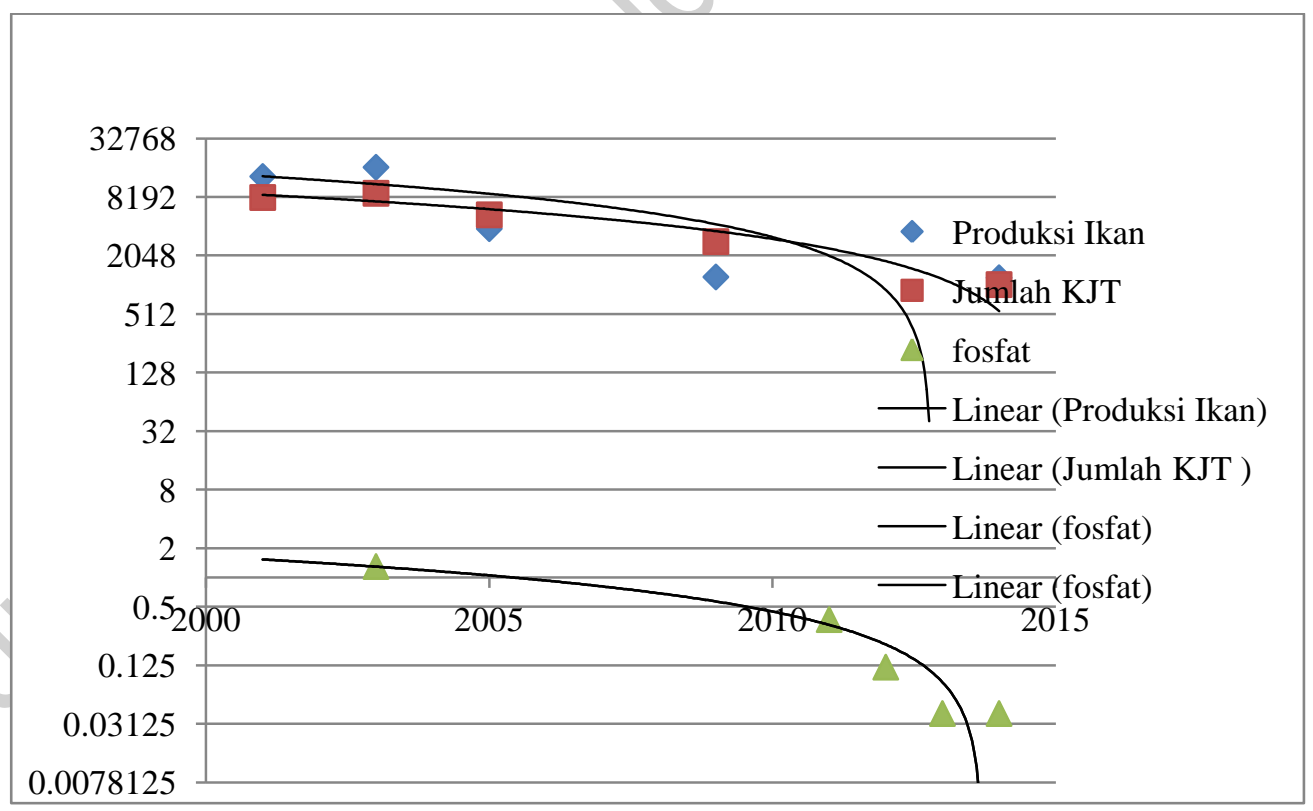

Gambar 2. Pendugaan hubungan linear antara waktu $(\mathrm{x})$ dengan produksi akuakultur $(\mathrm{Y})$, antara waktu $(\mathrm{x})$ dengan jumlah kjt yang beroperasi di danau tondano $(\mathrm{Y})$, dan antara waktu $(\mathrm{x})$ dan kandungan fosfat di perairan danau tondano. 